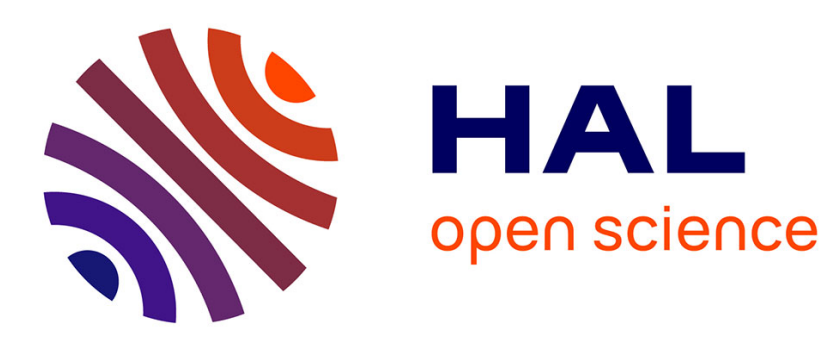

\title{
Evaluation of indirect effects of place-based science-industry transfer policies: Case of French Technological Research Institutes \\ Ruben Fotso
}

\section{To cite this version:}

Ruben Fotso. Evaluation of indirect effects of place-based science-industry transfer policies: Case of French Technological Research Institutes. 2020. halshs-02998262

\author{
HAL Id: halshs-02998262 \\ https://shs.hal.science/halshs-02998262 \\ Preprint submitted on 10 Nov 2020
}

HAL is a multi-disciplinary open access archive for the deposit and dissemination of scientific research documents, whether they are published or not. The documents may come from teaching and research institutions in France or abroad, or from public or private research centers.
L'archive ouverte pluridisciplinaire HAL, est destinée au dépôt et à la diffusion de documents scientifiques de niveau recherche, publiés ou non, émanant des établissements d'enseignement et de recherche français ou étrangers, des laboratoires publics ou privés. 
UMR 5824

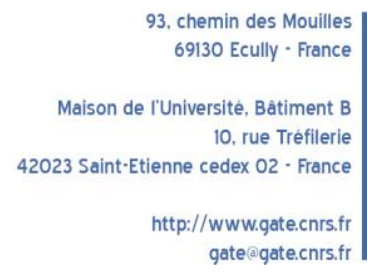

\title{
Evaluation of indirect effects of place-based science-industry transfer policies: Case of French Technological Research Institutes
}

\author{
Ruben Fotso
}

\begin{abstract}
:
When it comes to evaluating the causal effect of public policies on corporate performance, most studies tend toexclusively focus on targeted (treated) firms as if they have no relationship to the rest of the economy. Yet, public policies are highly likely to indirectly influence non-targeted firms due to the relationships they have with the targeted firms. This paper aims to fill this gap by evaluating the indirect causal effect of a new French science-industry transfer policy on the financial and employment variables of non-targeted companies. To do so, it focuses on French Technological Research Institutes (TRIs) which are science-industry collaborations based on technological platforms that bring together SMEs, large companies, universities and public research bodies with the goal of accelerating the transfer of knowledge towards firms and generating spillovers inside and outside the scheme. Based on geographical economics literature, it can be assumed that indirect effects tend to be spatially concentrated. By comparing a local untreated company to a non-local untreated company, therefore, using a difference-in-differences method applied to panel data (2008-2016) and combined with a double matching at the department level (NUTS 3) and at the firm level, it can be seen that non-beneficiary companies, located in the treated French department significantly improve their financial performance (turnover, financial autonomy) compared to control companies located in the control departments. The dynamics of employment variables are a little more complex. A negative significant effect is observed on the proportion of managers at the beginning of treatment and a positive significant effect is noticed later at the end of the period of observation. Analysis of the dynamics of the effects indicates that performance does not improve immediately after the treatment but later in time.
\end{abstract}

\section{Keywords:}

Indirect effect, impact evaluation, difference-in-differences approach, SMEs, spillovers

JEL codes:

C21, C53, D04, H23, O36

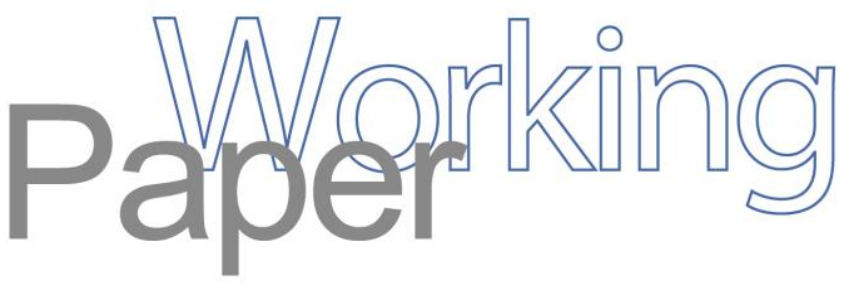




\title{
Evaluation of indirect effects of place-based science-industry transfer policies: Case of French Technological Research Institutes.
}

\author{
Ruben Fotso ${ }^{1}$
}

September 2020

\begin{abstract}
:
When it comes to evaluating the causal effect of public policies on corporate performance, most studies tend to exclusively focus on targeted (treated) firms as if they have no relationship to the rest of the economy. Yet, public policies are highly likely to indirectly influence non-targeted firms due to the relationships they have with the targeted firms. This paper aims to fill this gap by evaluating the indirect causal effect of a new French science-industry transfer policy on the financial and employment variables of non-targeted companies. To do so, it focuses on French Technological Research Institutes (TRIs) which are science-industry collaborations based on technological platforms that bring together SMEs, large companies, universities and public research bodies with the goal of accelerating the transfer of knowledge towards firms and generating spillovers inside and outside the scheme. Based on geographical economics literature, it can be assumed that indirect effects tend to be spatially concentrated. By comparing a local untreated company to a non-local untreated company, therefore, using a difference-in-differences method applied to panel data (2008-2016) and combined with a double matching at the department level (NUTS 3) and at the firm level, it can be seen that non-beneficiary companies, located in the treated French department significantly improve their financial performance (turnover, financial autonomy) compared to control companies located in the control departments. The dynamics of employment variables are a little more complex. A negative significant effect is observed on the proportion of managers at the beginning of treatment and a positive significant effect is noticed later at the end of the period of observation. Analysis of the dynamics of the effects indicates that performance does not improve immediately after the treatment but later in time.
\end{abstract}

Keywords: Indirect effect, impact evaluation, difference-in-differences approach, SMEs, spillovers

Code JEL: C21, C53, D04, H23, O36

\footnotetext{
${ }^{1}$ Univ Lyon, UJM Saint-Etienne, GATE UMR 5824, F-42023 Saint-Etienne, France
} 


\section{Introduction}

Science-industry transfer policies are aimed at promoting collaboration between science and industry players, often in a local or regional context, with a view to accelerating the transfer of knowledge produced by science to enterprises. They are based on the main idea that science (universities, public research organisations) is an ultimate producer of the new knowledge needed by industry (firms, start-ups) to generate product and process innovations (Nelson, 1993; Etzkowitz and Leydesdorff, 2000; Mowery and Sampat, 2007) and that technological innovations based on basic scientific research stimulate wealth creation and economic growth (Chai and Shih, 2016). These policies can take different forms depending on the context and objectives of the countries. Their main forms are: i) financial incentives for collaborative science-industry research. In this form, the actors involved are often organized in R\&D consortia, where activities are financed totally or partially by public authorities, depending on the funding model desired by the government; ii) researcher mobility programmes, which consist in encouraging academic researchers to work temporarily in companies; iii) cluster policies, which aim to facilitate collaborations between science and industry actors located in the same territory (FranceStratégie, 2018). Such policies include competitiveness clusters, science and technology parks, etc. In addition to these different forms that can be described as direct aid, there is also indirect aid, such as technology platforms (financed by public authorities) that interact with companies. In the platforms, researchers from the scientific community and those from the industrial community work together daily on joint projects using shared machinery and equipment located in the same place.

The objectives of innovation policies based on science-industry relations are varied. Generally speaking, these policies aim to create new products and processes, new technologies and to accelerate their commercialisation. To this end, they focus mainly on applied rather than basic research and target both large firms and SMEs (Nishimura and Okamuro, 2016). They aim to "strengthen innovation and boost the competitiveness of industry by promoting collaborations between companies, start-ups, universities and public research laboratories located in the same territory" (Ben Hassine and Mathieu, 2017). They also aim to strengthen territorial competitiveness in promising sectors of activity for which the territory already has a potential for knowledge, research and innovation (Dujardin, Louis, and Mayneris, 2015). Unlike other innovation policies, science-industry transfertype policies aspire to generate new scientific knowledge and economic growth so that they can benefit as many firms as possible beyond the direct beneficiaries and society as a whole (Chai and Shih, 2016). In other words, science-industry transfer-type policies aim to generate and disseminate scientific knowledge beyond the target population (direct beneficiaries) so as to also reach enterprises that are not specifically targeted but are linked to direct beneficiaries (indirect beneficiaries). For the sake of clarity, direct beneficiaries (treated firms) are those enterprises that participate in the TRI policy-i.e., they choose to actively participate in the activities included in the policy while indirect beneficiaries are those firms that do not participate in the policy, but because of the linkages they have with participants they may benefit from it.

It should be noted that spillovers or indirect effects from science-industry transfer innovation policies are potentially different from those of more generic innovation policies. This distinction stems mainly from the nature of the predominant research carried out in the context of each of these two innovation policies. To fully understand this difference, it should be noted that research conducted in the context of science-industry transfer innovation policies is much more basic research in the sense that science tends to conduct exploratory activities that generate new knowledge (March, 1991, Faerms et al., 2004); whereas research conducted in the context of more general innovation policies is more applied because the main actors (firms) tend to carry out exploitation activities that consist in significantly improving existing knowledge (March, 1991). The difference between the two spillovers can be examined at several points, notably in terms of typology, nature, degree of diffusion and magnitude. In terms of typology, basic research has two types of potential spillovers: intra-industry spillovers and cross-industry spillovers, while applied research has only intra-industry_spillovers (U., Akcigit, D., Hanley \& N., Serrano-Velarde , 2020). This could be explained by the fact that basic research often has applications in many industries other than that for which it was originally intended, while applied research generally remains in the industry for which it was originally intended (Nelson, 1959). In terms of nature, the fact that the results of basic research can be used in several areas suggests that spillovers from basic research are generic in nature, whereas applied research is very specific, as it is aimed at only one area. Thus, the spillovers generated by science-industry transfer policies can be said to be generic in nature, whereas those generated by more general innovation policies are domain- or industry-specific. In terms of magnitude and degree of diffusion, the spillovers of science-industry transfer innovation policies are more diffused and of greater magnitude than those of more generic innovation policies. Indeed, within the framework of more general innovation policies, the enterprises are involved carry out R\&D activities with the objective of short-term economic profitability. In this context, they take protective measures (patents, secrecy, contractual mechanisms, etc.) against the leakage of 
knowledge so that it does not benefit competing firms. As a result, their attitude will lead to a reduction in the extent and spread of knowledge. Knowledge leakage is therefore unintentional and of low amplitude compared to that of innovation policies of science-industry transfer, where scientific actors (universities and/or public research organisations) are known for their openness to research and therefore often seek to make their scientific discoveries known through scientific publications and conferences, etc. They are keen to disseminate the knowledge produced, which will ultimately benefit a greatest number of companies. Their attitude on the part of these actors will rather increase the scale of the spillovers and make them more diffuse. Due to the specificity of spillovers of science-industry transfer policies, it is therefore important to conduct more empirical research to assess them.

Most evaluative work (Lundmark and Power, 2008; Giuliani and Arza, 2009; Dessertine, 2014; Brossard and Moussa, 2014; Dujardin et al, 2015; Chai and Shih, 2016; Ben Hassine and Mathieu, 2017; Bellucci et al., 2018) on the effect of science-industry transfer policies have not considered non-beneficiaries by implicitly making the assumption that there would be no interaction between direct beneficiaries and non-beneficiaries. Therefore, the objective of this work is to evaluate and analyse the effect of science-industry transfer policies by exclusively focusing on non-beneficiaries and, in order to improve innovation policy decisions. To do so, it seeks to design a framework for evaluating the indirect effects and considers a specific case of the French Technological Research Institute (TRI) known as "Nanoelec" which was created in Grenoble in 2012 and is based on technological platforms. A TRI is an interdisciplinary thematic research institute that brings together higher education and research institutions, major groups and SMEs working together on technological platforms around a common technological research agenda, in order to accelerate the transfer of scientific knowledge from the public to the private sector. The Nanoelec TRI is one of the eight French TRIs that were created across France as part of one of the vast French programme known as the "Programme d'Investissement d'Avenir (PIA)"2. Powered by CEA ${ }^{3}$ via its institute $\mathrm{LETI}^{4}$, Nanoelec is focusses mainly on the three-dimensional integration of chips and photonics on silicon, which are key technologies for integrated circuits of the future. The focus on Nanoelec is quite simply due to the fact that we have access to internal data on the companies that participated in it. We use firm-level micro-economic data on French SMEs observed over the 20in 08-2016 period to estimate the indirect causal effect of Nanoelec.

In order to measure the indirect effects generated by Nanoelec, the study follows the literature on spillover effects and agglomeration economies. Indeed, several studies (Sveikauskas, 1975; Shefer, 1973; Ciccone and Hall, 1996; Ellison et al.,2010; Adams and Jaffe, 1996; etc.) have hypothesized and provided empirical evidence that firms' performance benefits from agglomeration economies (Garone et al.., 2014) and that these agglomeration economies, first identified by Marshall (1920) and studied in more detail by Arrow (1962) and Romer (1986), originate from industry- or location-specific spillovers due to knowledge or technology spillovers, customer-supplier dependencies and labour market pooling. For example, Sveikauskas (1975) showed that productivity is generally higher in large cities, while Shefer (1973) showed that productivity is higher when the size of the industry is larger. Ciccone and Hall (1996) found that doubling employment density significantly increases average labour productivity. Adams and Jaffe (1996) measure intra-industry spillovers based on the Cobb-Douglas transformed production function to account for the effect of geographic and technological proximity of R\&D activity. They show that the productivity improvement effect of $R \& D$ declines with increasing geographical and technological distance. Ellison et al. (2010) studied the relevance of Marshall's three mechanisms of industrial agglomeration and their results suggest that customer-supplier dependency is the most important factor, followed by labour pooling. Moreover, the literature has referred to the concept of industryspecific local externalities (ISLE) to explain the channel through which firms can benefit from spillovers. Henderson et al (1995) refer to these types of industry-specific externalities arising from regional agglomeration as "locational externalities", particularly when firms operate in related sectors and are located nearby._Following this literature, geographical and industrial dimensions are used to define indirect beneficiairies and therefore suppose that geographical proximity within a sector is the main channel through which external effects occur. We define indirect beneficiaries as firms that are not beneficiaries of Nanoelec actions but are located close by and belong to the same industries as the direct beneficiaries. It is assumed that because they are located close to a

\footnotetext{
${ }^{2}$ In English, "Investment in the future programme".

${ }^{3}$ The Commission for Atomic Energy and Alternative Energies is a French public scientific research organisation in the fields of energy, defense, information technologies, material sciences and life and health sciences, based in ten sites across France. Historically known as the Atomic Energy Commission (CEA), it changed its name in 2010 and expanded its scope to alternative energies.

${ }^{4}$ The Laboratory of Electronics and Information Technology (LETI) is one of the world's leading applied research centres for microelectronics and nanotechnology. Based in the scientific polygon in Grenoble, France, it is one of the 34 members of the network of Carnot institutes to promote innovation and economic dynamism in collaboration with industry.
} 
source of knowledge that is the TRI and close to firms benefiting directly from the TRI, non-beneficiary firms belonging to the same sectors as the direct beneficiaries can benefit from the spillover effects generated by the concentration of TRI resources. The empirical strategy consists firstly of defining and establishing the reference group, i.e., firms that may potentially be affected by the external effects; secondly of defining a framework for assessing the indirect effects; and thirdly of using the fixed-effects estimator applied in a difference-indifferences model combined with double matching at the firm level and at the level of the geographical areas of the policy, in order to select the appropriate control group. This addresses potential problems of endogeneity and selection bias.

Our results show that Nanoelec increased the turnover and financial autonomy of indirect beneficiaries compared to control companies. Analysis of the dynamics of the results indicates that the indirect effects do not immediately appear after treatment but only a few years later. Furthermore, these positive indirect effects appear to increase over time. With respect to employment variables, the results reveal a more complex dynamic. There is a negative indirect effect on the proportion of managers in the first year of implementation of TRI and a positive indirect effect a few years later on the same variable. In analysing the permanence of these effects, only the effects on financial performance appear to be persistent since the establishment of the TRI. The first contribution this paper makes is methodological in the sense that it proposes a method for evaluating indirect effects through an original construction of a counterfactual of indirect beneficiaries to measure these effects. In other words, this paper helps to relax the hypothesis of the absence of interactions between treated firms and untreated firms. This article also contributes to the literature on the effect of place-based innovation policies in that TRI policy is based on the principle of regionality, meaning that they have been established taking into account regional particularities and that it aims to have indirect effects passing through by the proximity relations on the region. Finally, this paper provides original empirical results on the effectiveness of Nanoelec on the performance of untreated SMEs. In other words, it helps to demonstrate that firms not directly beneficiaries of Nanoelec services still improve their performance because of their geographical and technological proximities to the direct beneficiaries and to this TRI.

The rest of the paper is structured as follows. Section 2 presents a literature review focusing, on the one hand, within a theoretical framework, on the relationship between geographical proximity and the indirect effects of science-industry transfer policies and, on the other, on empirical studies on the evaluation of the indirect effects of those policies. Section 3 explains econometric evaluation strategies while Section 4 presents evaluation results. Section 5 focuses on the explanations and implications and Section 6 provides the conclusion and some recommendations in terms of public policy.

\section{Literature review}

\subsection{Theoretical framework: geographical proximity and indirect effects of place-based science-industry transfer policies}

Analysis of the indirect effects of place-based science-industry transfer policies has received very little attention both theoretically and empirically. Very often, researchers are more interested in the effect of these policies on direct beneficiaries, thus ignoring firms that are likely to benefit indirectly from the returns from place-based science-industry transfer policies because of their interactions, circumscribed in a given space, with direct beneficiaries. In an economy, firms do not evolve in isolation insofar as they maintain more or less close relations with other firms. This means that any disruption or change in a beneficiary firm is likely to have repercussions on the firms with which it is linked. In this context, the research question that arises regards the possible transmission channels through which the indirect effects of these policies are likely to emerge and to what extent these effects can be reduced by distance. This question is very important as it seeks to address one of the challenges of these policies, which is to generate socio-economic benefits so that they can reach beyond the direct beneficiaries to reach local untreated companies.

Analysis of theoretical literature on geographical economy and on the geography of innovation reveals at least three ways in which place-based science-industry transfer policies are likely to have an effect upon local firms that are not directly beneficiary. Indirect effects can be observed via knowledge flows, via commercial transactions and via the labour market.

\section{Indirect effects via knowledge flows}


Firms that have made no effort to carry out R\&D activities can still benefit, free-of-charge or at a lower cost, from the knowledge flows of enterprises that do perform R\&D activities. This is the case, for example, with patents, which are entirely public. Anyone can access a patent, read it, understand it and use this knowledge to innovate (Garone et al., 2014). It is also the case of cooperative relationships with incomplete contracts due to the difficulty or even impossibility of predicting future eventualities (Gallié, 2004). In this context, it becomes feasible to consider that firms not supported by an innovation policy could, in spite of everything, benefit from the flows of voluntary or involuntary knowledge from direct beneficiary firms due to market failures such as imperfect appropriability of knowledge, incomplete contracts, etc. However, it should be noted that non-treated firms can only effectively benefit from the spillovers of innovation policies if they have a sufficiently strong absorptive capacity to understand, exploit and assimilate external knowledge (Cohen and Levinthal, 1989) and if they frequently interact actively with sources of spillovers (public laboratories, universities, etc.) to capture the benefits of their research (Cockburn and Henderson, 1998; Zucker, Darby, and Armstrong, 1994).

Moreover, work in the geography of innovation has highlighted the regional dimension of these knowledge flows. Agglomeration effects would be greater for R\&D and innovation activities than for production activities. This stylised fact is based on the argument that the transmission of knowledge is hampered by geographical distance because it involves intense interpersonal relations and repeated face-to-face encounters (Madiès and Prager, 2008). Thus, geographical proximity is said to play an important role in knowledge transfer and acquisition (Davenport, 2005). This geographical proximity is all the more important when accessing tacit knowledge (Löfsten and Lindelöf, 2001), which has the consequence of promoting the concentration of innovation in space. Research work in France has shown that the diffusion of knowledge spillovers diminishes with distance. This is the case of the work by Autant-Bernard and Massard (2004) carried out on the French departmental level, which shows that the more distantly R\&D activities are conducted, the more the effects on local innovation diminish. Other works, such as that by Massard and Riou (2003), suggest that there would be a real "border effect" between departments. Specifically, knowledge spillovers would decrease significantly when crossing the border of a contiguous department of order 1, and would cancel each other out for a contiguous department of order 2. In the framework of science-industry relations, geographical proximity between scientific and industrial communities is even more important in this respect as public research is, by its very nature, fundamental and therefore generates a lot of tacit information, access to which requires frequent contact between public and private researchers. It is in this respect that geographical proximity is more important for the integration of academic resources and local capacities (Asheim and Isaksen, 2002).

In short, place-based science-industry transfer policies can indirectly influence the performance of non-directly beneficiary firms because of their geographical proximity to direct beneficiary firms, as long as they have a strong absorption capacity (technological proximity) and that they increase contacts with direct beneficiaries.

\section{Indirect effects via customer-supplier links}

Indirect effects can occur through the business relationships that the direct beneficiaries of innovation policies have with their customers and suppliers. These effects could be analysed under two types of links: the direct beneficiaries - customers link and the suppliers - direct beneficiaries link.

In the first link, the direct beneficiary firm may produce intermediated goods or innovative equipment that are the inputs for its client firms. If it appears that the price at which these innovative inputs are sold does not fully reflect the quality changes incorporated by innovative goods, then there will be a shift in productivity gains from producer to customer (Terleckyj, 1974; Goto and Suzuki, 1989; Verspagen, 1997; Crespi, Criscuolo, Haskel and Slaughter, 2008; Nishimura and Okamuro, 2016). Griliches (1979) describes this shift as "pecuniary spillovers" by distinguishing between knowledge spillovers and pecuniary spillovers. According to this author, pecuniary spillovers occur when economic benefits are transferred through market transactions, while knowledge spillovers occur when knowledge is transferred without a market transaction (Nishimura and Okamuro, 2016). Pecuniary spillovers become important when competition is fierce, as this reduces the bargaining power of the direct beneficiary firms. Consequently, a firm may benefit from the indirect effects of an innovation policy because it is a customer of one or more direct beneficiary firms. On the other hand, by reasoning inversely, it could be supposed that if the beneficiary firm holds a monopoly, then it could charge very high prices, which will have a negative effect on the productivity gains of customers.

In the second link, innovation policies are likely to increase the R\&D and innovation activities of direct beneficiaries, which could result in an increase in their need for intermediate or capital goods. An increase in orders for intermediate goods from supplier firms, could therefore be expected, which will have an effect on their financial performance, in this case, turnover. Thus, it can be assumed that when the treatment of direct beneficiaries begins, positive indirect effects on the performance of indirect beneficiaries are likely to be 
observed if the majority of these indirect beneficiaries are suppliers. However, it is possible that place-based science-industry transfer policies may exasperate the agglomeration, ultimately producing negative effects. Some authors such as Barbesol and Briant (2008) have studied the negative effects of an agglomeration. The high concentration of economic activities can lead to additional costs of production factors. For example, there may be a sharp rise in the prices of wages, land and capital. Negative spillovers of production such as pollution, congestion of transport networks can also be observed, which can reduce the productivity of firms and thus their performance. Areas where economic activity is highly concentrated are followed by increased competition.

Furthermore, work in geographical economics has highlighted the fact that the activities of the economic system (production, consumption, distribution, etc.) can be polarised and that this concentration can be explained by agglomeration economies. Specifically, firms tend to cluster spatially close to customers and suppliers in order to benefit from low transport costs, easy access to a variety of intermediate goods and the presence of a larger number of easily accessible consumers (Barbesol and Briant, 2008). Considering the interactive model of innovation process, there is a strong case for customers and suppliers playing an important role in the innovation process because they have relevant knowledge and experience of the processes, products (Oerlemans, Meeus and Boekema, 2001) and can therefore provide information and knowledge on the product functions and quality needed to solve problems (Lundvall, 1992). In this context, agglomeration facilitates the bringing together of companies and potential customers on the one hand and companies and suppliers on the other (Duranton and Puga, 2004).

In conclusion, place-based science-industry transfer policies can generate positive or negative indirect effects through trade relations, depending on the degree of agglomeration, competition and the type of trading partner.

\section{Indirect effects via the skilled labour market}

place-based science-industry transfer policies do not always generate positive indirect effects. They are likely to create distortions in the skilled labour market by having a negative effect on the employment variables of local firms that are not supported. Indeed, skilled labour is one of the most important factors in innovation process. Several studies have shown that skilled workers are at the heart of innovation process because they carry out R\&D activities and master the latest developments (Guellec, 1996; Mangematin and Nesta, 1999). They are the main agents of absorption capacity in that they play an important role in the acquisition and transmission of external knowledge within the company (Cohen and Levinthal, 1989; Tushman and Katz, 1980) and they are the main actors in cooperative relations in $R \& D$ to the extent that they encourage cooperative relations with others with similar skills outside the company, thus facilitating access to external knowledge networks, in particular in the case of the use of scientific knowledge (Rothwell and Dodgson, 1991; Mangematin and Nesta, 1999).

However, skilled labour is very expensive, which constitutes a barrier to the development of enterprises, in this case SMEs with limited financial resources. Moreover, skilled labour is sometimes difficult to access in certain regions. As a result, place-based science-industry transfer policies policies aim to put in place incentives to help firms attract the best candidates to a given area, which has the direct consequence of increasing the employment pool. However, some studies such as that of Barbesol and Briant (2008), point out that in a larger employment pool, workers tend to be more specialised and therefore more productive. In other words, place-based scienceindustry transfer policies cause a rise in the wages of skilled workers, which could lead to a situation where beneficiary (treated) firms hire more skilled workers (because they are supported) to the detriment of non-treated local firms, which will find it difficult to access skilled labour that was already expensive before the policies were put in place. From a dynamic perspective, Garone et al. (2014) confirm these observations by pointing out that the indirect effects on skilled employment could be negative in the short term among indirect beneficiaries and over time they could fade and become positive, as spillovers spread to indirect beneficiaries and additional jobs begin to relocate outside the local economic system. These authors focus on timing and gestation periods in order to fully understand the meaning of these effects.

In addition, work in the geographical economy and geography of innovation has highlighted the spatial dimension of the skilled labour market. This means that firms tend to concentrate in regions where it is easy to find a labour force. In the context of science-industry relations, some authors such as Anselin, Varga and Acs (1997) point out that beyond its role as a producer of basic research, the university plays another role which is the creation of human capital in the form of highly qualified workers. Other studies (Bartel and Lichtenberg, 1987; Lucas, 1988, etc.) $)^{5}$ also show that the university plays an important role in the creation of technological innovations through the development of human capital. In this context, university is an important locational

\footnotetext{
${ }^{5}$ Cited by Anselin et al. (1997)
} 
magnet for private sector R\&D and high-tech production (Malecki, 1991; Anselin et al.,1997). Numerous empirical studies have shown that the presence of universities has a significant, positive effect on the location of high-tech production, new start-ups and research and development facilities (see the work of Malecki, 1986; Nelson, 1986; Harding, 1989; etc.). This therefore implies that the indirect effects via the skilled labour market have a regional dimension.

Table 1: Types of indirect effect

\begin{tabular}{|l|l|l|}
\hline Type of effects & Main theoretical mechanisms & Key references \\
\hline Indirect effects via knowledge flows & $\begin{array}{l}\text {-Market failures (knowledge spillovers, } \\
\text { imperfect appropriability of knowledge, } \\
\text { incomplete contracts, etc.) }\end{array}$ & $\begin{array}{l}\text { Garone } \text { et al., 2014 } \\
\text { Gallié, 2004 } \\
\text { Cohen and Levinthal, 1989 } \\
\text { Cockburn and Henderson, 1998; Zucker } \text { et al., 1994 } \\
\text { Löfsten and Lindelöf, 2001 } \\
\text { Davenport, 2005 }\end{array}$ \\
$\begin{array}{ll}\text {-Active interaction } \\
\text { - Agglomeration economies }\end{array}$ & $\begin{array}{l}\text { Griliches 1979 } \\
\text { Nishimura and Okamuro, 2016 } \\
\text { Barbesol and Briant, 2008 } \\
\text { Duranton and Puga, 2004 } \\
\text { Lundvall, 1992 }\end{array}$ \\
\hline Indirect effects via customer-supplier links & $\begin{array}{l}\text {-Pecuniary spillovers } \\
\text { - Market structure } \\
\text {-Change in the order of intermediate goods. }\end{array}$ & $\begin{array}{l}\text { Barbesol and Briant (2008), } \\
\text { Garone } \text { et al. (2014) } \\
\text { Anselin } \text { et al.,1997 }\end{array}$ \\
\hline Indirect effects via the skilled labour market & $\begin{array}{l}\text {-Market distortion } \\
\text {-Specialization }\end{array}$ & \\
\hline
\end{tabular}

\subsection{Empirical literature: evaluation of the indirect effects of science-industry transfer devices}

Empirical literature on the evaluation of indirect effects of innovation policies based on science-industry relationships is almost non-existent. This limitation in the literature is important to underline insofar as it is inconsistent with the foundations of science-industry transfer policies, which, compared to other innovation policies, aim to disseminate scientific knowledge to the greatest number of firms in order to affect their performance beyond direct beneficiaries. In other words, these policies aim to maximise the presence of knowledge spillovers.

Very few empirical studies have been interested in evaluating and analysing the indirect effects of innovation policies in relation to all categories (Garone et al., 2014; Castillo, Maffioli, Rojo, and Stucchi, 2014; Nishimura and Okamuro, 2016; Di Gennaro and Pellegrini, 2017). Of these studies, the only one that focused on scienceindustry transfer policies is that of Nishimura and Okamuro (2016). Since our article focuses on the spatial dimension of indirect effects, in addition to presenting the study by Nishimura and Okamuro (2016), in this empirical literature review we will look at the work of Garone et al. (2014) and Di Gennaro and Pellegrini (2017), for the main reason that these two empirical studies have to the same focus on the spatial dimension of indirect effects.

Nishimura and Okamuro (2016) seek to assess the direct and indirect causal effect of a Japanese governmentfunded R\&D consortium programme on companies. This programme exclusively sponsors R\&D projects of a science-industry type i.e., including at least one university and one private company. The funding ("treatment") started in 1997 for a duration of two years [1997-1998]. To assess the indirect effects of this programme, the authors focus on commercial relations as the main channel for the transmission of indirect effects. More specifically, they seek to evaluate the effect of this programme on the client firms of consortium firms. The firstdifference propensity score-matching method indicates that the clients of consortium firms improve their sales of innovative products, labour productivity, and total factor productivity compared with firms that do not have business relationships with consortium firms. Comparing large and small firms, they find that only large customers benefit from pecuniary spillovers (via business transactions). Unlike Nishimura and Okamuro (2016) who assesses indirect effects via trade relations, Garone et al. (2014) focuses on geographical proximity to assess the indirect effects of a cluster policy in Brazil on three outcome variables: employment growth, total value of exports and the probability of exporting. In order to measure the indirect effects generated by this policy, the authors assume that geographical proximity within a sector (industry) is the main channel through which spillovers occur and consider the municipality as a proxy variable for the location of policy where there are a positive number of direct beneficiaries in the same industry. The results obtained through the combination of a fixed-effects model and the reweighting methods applied to the panel data (2002-2009) indicate a negative short-term indirect effect on employment in the first year after the implementation of the policy and a positive 
medium- and long-term indirect effect on export variables. The results also underline the importance of taking into account the timing and gestation periods of the effect on firm performance when evaluating cluster policies. Like the previous study, Di Gennaro and Pellegrini (2017) focus on the geographical dimension and consider the municipality as a policy influence area in order to assess and analyse the indirect effects of public R\&D policies on firms' R\&D expenditures. To do so, they propose a framework for causal inference in the presence of spatial interactions within a new hierarchical spatial difference-in-differences model. In addition, the major innovation of this approach is it makes it possible to assess the indirect effects differentiated between treated and controls. Applying this approach to a sample of 2,389 companies, 145 of which were treated, observed over between 2007 and 2013, the estimates show positive and significant indirect effects on direct beneficiaries and negative and significant indirect effects on indirect beneficiaries.

Very little attention has been paid to measuring the indirect effects of innovation policies in general, and scienceindustry transfer-type innovation policies in particular. It is therefore very difficult to draw definitive conclusions. Nevertheless, a few important points can be made. The first point is inherent to the methodology. The evaluation method adopted by Nishimura and Okamuro (2016) does not appear to be robust. These authors use the first difference method to estimate the indirect effect of treatment, which consists in differentiating between the performance of indirect beneficiary firms and control firms. In other words, this method does not control for unobserved variables that are stable over time and that may have an effect upon the treatment and the performance of the firms. Furthermore, this study evaluates indirect effects 10 years after treatment, which may suggest that other factors could have intervened, such as an annual shock, to explain the variations in the outcome variables. However, in their model specification, the authors do not take into account annual fixed effects, which renders their evaluation model not very robust. These limitations are taken into account by Di Gennaro and Pellegrini (2017) who use a difference-in-differences model that controls for heterogeneity, temporal fixed effects, and time-constant factors.

The second point concerns the evaluation results. Since, to our knowledge, only one study has evaluated the indirect effects of science-industry transfer-type devices, it is difficult to generalise estimated results on the specific indirect effect of place-based science-industry transfer policies. Nevertheless, if one sticks to the results of analyses without distinction of the type of innovation policy, it can be seen that of the few existing studies, the results tend to reveal additionality on the socio-economic performances of indirect beneficiary enterprises, regardless of the path by which the spillovers spread (see the work by Nishimura and Okamuro 2016; Garone et al., 2014 and Di Gennaro by Pellegrini, 2017). It should be noted that the number of empirical studies available is not sufficient to confirm this observation. However, there is reason to believe that additionality would be observed rather on socio-economic performance. Moreover, analysis of the dynamics of indirect effects seems to show that these effects do not appear directly after treatment but some years later. There would therefore be a time lag between the treatment and the appearance of indirect effects. The third point concerns the channels through which indirect effects are transmitted. Empirical literature points to at least two channels through which indirect effects can occur: commercial relations between treated and untreated firms (Nishimura and Okamuro 2016) and spatial proximity (Di Gennaro and Pellegrini 2017 and Garone et al., 2014) which is not a transmission channel per se but rather a facilitator of several types of possible interactions.

\section{Empirical analysis}

\subsection{Context and "Technological Research Institute" policy}

In the aftermath of the 2008 crisis, which greatly affected France and its partners, the French government wanted to go beyond economic responses and carry out structural action by launching a vast investment programme known as the "Programme d'Investissement d'Avenir" (investment in the future programme). With a current budget of 57 billion euros, this programme focuses particularly on several major areas including higher education, training and research; industrial sectors and SMEs; the digital economy; sustainable development; etc. More specifically, the programme is based on several actions, including the creation of the Technological Research Institutes (TRIs) in 2012. Focusing on relationships between science and industry, these TRIs are justified by the particular context that is commonly known as the "European paradox", which can also be seen in France as a whole. This paradox refers to the lack of efficiency in innovation despite relatively high levels of public and private research. Indeed, various OECD reports reviewing national innovation policies in France have revealed gaps in the exchange of knowledge between science and industry. These TRIs emerged as a response to this particular situation. A TRI is an interdisciplinary thematic research institute that brings together higher education and research institutions, major groups and SMEs working together on technological platforms around 
a common technological research agenda, in order to accelerate the transfer of scientific knowledge from the public to the private sector.

One of the specificities of the TRIs compared to existing devices lies in their ability to make heterogeneous actors work together (companies and start-ups on the one hand and universities and public research organisations on the other) through multilateral (as opposed to bilateral) cooperation, co-located, based on technological platforms and high-level research teams. The cost to the taxpayer of the eight TRIs created in France over eight years (2012-2020) was 2 billion euros, reflecting the expectation that this initiative will bring substantial rewards for French society that are important to secure. Fifty percent of TRI activities are financed by public sector funding and $50 \%$ comes from private actors. Unlike direct R\&D aid, where the company receives a financial incentive to engage in R\&D cooperation, under this form of support, the company pays an R\&D service in order to collaborate on a multilateral basis with public and private scientific stakeholders through the platform. In other words, there are no specific eligibility conditions. All companies without exception can participate in the TRI as long as they can pay $50 \%$ of the market price for R\&D services. The peculiarity of science-industry transfer platforms is that they accelerate the transfer of knowledge and technologies within companies, thus reducing the shift from R\&D to industrial production. Furthermore, one of the characteristics of the TRI is the concentration of resources in one geographical location. This physical presence translates into the creation of new opportunities, the bringing together of players and thus the development of collaborative networks (Levet and Mathieu, 2010). Thus, the concentration of activities in the same place is likely to generate knowledge spillovers and agglomeration economies beyond the ecosystem.

In this study, we focus on the Nanoelec TRI which is one of the eight French TRIs that were created across France as part of one of the vast French programme known as the "Programme d'Investissement d'Avenir (PIA)"6. The focus on Nanoelec is quite simply due to the fact that there is access to internal data on the companies that participated in it. Powered by CEA ${ }^{7}$ via its institute LETI $^{8}$, Nanoelec's theme is nanoelectronics and focuses mainly on the three-dimensional integration of chips and photonics on silicon, which are key technologies for the integrated circuits of the future. The amount of public funding for Nanoelec is approximately 160 million euros over the period 2012-2020.

\subsection{Empirical approach}

The purpose of this section is to present the methodology to assess the indirect causal effect of the Nanoelec TRI on the financial and employment variables of SMEs. More specifically, this study is based on three financial indicators (turnover, equity and financial autonomy) and three employment indicators (total employment, number of managers and proportion of managers). These variables were chosen for at least three reasons. The first reason is relative to the empirical literature on the evaluation of indirect effects of innovation policies. Of the few existing studies, most empirical work focuses on socio-economic performance (see the work by Garone et al., 2014; Nishimura and Okamuro 2016; Castillo et al. 2014; etc.). Thus, choosing these variables could enable us to better compare our results with those in the literature. The second reason is related to TRIs themselves. TRIs are based on technological platforms that aim at accelerating the transfer of innovation to firms and consequently at reducing the time of transition from $R \& D$ to industrial production and from industrial production to the economic performance of firms. The third reason is inherent to the transmission mechanisms of indirect effects. In our theoretical literature review, we have shown that indirect effects can affect the socioeconomic performance of firms, notably via commercial transactions (supplier-customer links) and via the skilled labour market.

We define "indirect effect" as the effect of the TRI on firms that have not directly benefited from the TRI's actions but which, because of their geographical and technological proximity to the TRI and their interactions with local beneficiary firms, are likely to benefit from the likely spillovers. These companies are referred to as "indirect beneficiaries". In the ex-post evaluation of indirect effects, the main challenge in the evaluation design

\footnotetext{
${ }^{6}$ In English, "Investment in the future programme".

${ }^{7}$ The Commission for Atomic Energy and Alternative Energies is a French public scientific research organisation in the fields of energy, defense, information technologies, material sciences and life and health sciences, based in ten sites across France. Historically known as the Atomic Energy Commission (CEA), it changed its name in 2010 and expanded its scope to alternative energies.

${ }^{8}$ The Laboratory of Electronics and Information Technology (LETI) is one of the world's leading applied research centres for microelectronics and nanotechnology. Based in the scientific polygon in Grenoble, France, it is one of the 34 members of the network of Carnot institutes to promote innovation and economic dynamism in collaboration with industry.
} 
is to identify the group of indirect beneficiaries and the appropriate comparison group (Angelucci and Maro, 2015). The main concern is to ensure that the group of indirect beneficiaries corresponds to non-beneficiary firms, which are indeed likely to be affected by localised indirect effects only because of their geographical and technological proximity to the TRI under study and their interactions with local beneficiary firms. Following the literature on the different channels of transmission of indirect effects, the indirect beneficiaries are defined in this study by the criteria of geographical proximity and industrial (technological) proximity. Following the literature on spillover effects and agglomeration economies, we assume that "spatial proximity in an industry" is the main channel for the transmission of indirect effects. In other words, we assume that the indirect beneficiaries are firms that did not participate in the TRI, are local, and belong to the same industries as direct beneficiaries. This particular channel seems particularly well suited to the policy of TRIs in that TRIs are localised innovation support structures that concentrate significant material, technical and human resources in one place and are based on specific themes. Consequently, the concentration of these different resources in the same place is likely to generate external effects that may positively or negatively affect companies that are not directly involved in R\&D projects with TRIs but are located to the proximity of the TRI and whose research activities correspond to the themes developed within the TRI.

In developing the indirect effects evaluation method, we were inspired by the article by Angelucci and Maro (2015) on the relationship between programme evaluation and spillover effects. Two parameters of interest should be considered: (1) firms that can be treated $(E=1)$ or not $(E=0)$ and (2) zones or geographical areas in which the policies (the TRI) have been implemented. There are therefore treated areas $(Z=1$, i.e., the local economy in which the policy has been implemented) and untreated areas $(Z=0)$. With regard to zones, a question may arise on the size of the optimal geographical area for better observing indirect effects. In this study, we assume that our geographical area is at the departmental level (NUTS 3). This choice is guided by numerous empirical studies carried out in France on the departmental level, which seem to show that indirect effects would be contained within the department (see the work of Autant-Bernard and Massard, 2004; Massard and Riou, 2003). In this case, the "Isère" department will be considered as a treated area, as it corresponds to the department hosting the Nanoelec TRI. The untreated areas are all the other departments in the country (France), including those hosting the seven other TRIs in France. The choice to include the other TRI departments is linked to the fact that the TRIs are fundamentally different and belong to different industries. Given that the industry is one of the control variables, it is therefore impossible to find an SME whose activity is inherent to more than one TRI and, consequently, it will be impossible to find SMEs that belonging to other TRIs among the control group.

Since treated and untreated departments are not randomly selected, it is highly likely that these two groups of departments have observable or unobservable characteristics that may have an effect both on the performance of firms located there and participation in the TRI. In this context, a sample of untreated departments $(\mathrm{Z}=0)$ would not necessarily be comparable to a sample of treated departments $(Z=1)$. As a result, indirect beneficiaries might perform differently from the control firms even in the absence of a TRI due to departmental heterogeneity. For this reason, it is important to select control departments, i.e., untreated departments that are sufficiently similar to the treated department. Similarly, since indirectly treated and untreated firms are not randomly selected, direct comparison between these two groups of firms would lead to biased results due to the problem of selection bias (Garone et al., 2014). As a consequence, indirect beneficiaries might perform differently from control firms even in the absence of a TRI due to the individual heterogeneity of firms. All this means that the group of non-directly treated firms in the "treated" departments $(E=0, Z=1)$ cannot be directly compared to the group of non-directly treated firms located in the "non-treated" departments $(E=0, Z=0)$ due to these different heterogeneities, which are likely to affect both the result variables and participation in the TRI. Comparing these two groups of firms would therefore lead directly to biased estimation results.

In order to control for observable or unobservable variables at both firm and departmental level which are likely to influence both firm performance and participation in the TRI, it is traditionally recommended to use matching methods in order to select control units. In this case, matching should be carried out at two levels: at the departmental level in order to select "non-treated" departments with profiles similar to those of "treated" departments, i.e., Isère, and at the firm level in order to select control firms located in control departments. It is customary to select the control units using traditional matching methods based on statistical tools that require a sufficient sample size. However, in the case of control departments, it is impossible to use these methods because there is only one treated department, Isère. In this context, classification methods seem appropriate in order to constitute the homogeneous groups of departments. Thus, the control departments are those belonging to the same group as Isère.

The combination of our parameters of interest $(\mathrm{E}, \mathrm{Z})$ gives us four groups of companies: 
(1) $E=1, Z=1$ : treated companies located in the treated areas.

(2) $\mathrm{E}=1, \mathrm{Z}=0$ : treated companies located in the control areas.

(3) $E=0, Z=1$ : control firms located in treated areas.

(4) $E=0, Z=0$ : control firms located in control areas.

In our study framework, the indirect treatment effect (ITE) is estimated by comparing non-TRI firms located in treated areas (3) with non-TRI firms located in control areas (4). Assume that the variables $\mathrm{Y}_{0}$ and $\mathrm{Y}_{1}$ are the potential outcomes in the absence and presence of treatment, respectively. If the "CIA" and "SUTVA ${ }^{10 "}$ hypotheses are verified, then the indirect effect of treatment is given by the following equation:

$$
\mathrm{IET}=\mathrm{E}\left(\mathrm{Y}_{1}-\mathrm{Y}_{0} / \mathrm{E}=0, \mathrm{Z}=1, \mathrm{P}(\mathrm{X})\right)=\mathrm{E}(\mathrm{Y} / \mathrm{E}=0, \mathrm{Z}=1, \mathrm{P}(\mathrm{X}))-\mathrm{E}(\mathrm{Y} / \mathrm{E}=0, \mathrm{Z}=0, \mathrm{P}(\mathrm{X}))(5)
$$

With $\mathrm{P}(\mathrm{X})$ being the propensity score.

Our evaluation is based on the paired difference-in-differences model with fixed effects applied to panel data. The advantage of this combination of methods is that it takes into account non-observable time-invariant factors, such as individual fixed characteristics and trend effects (Bellucci et al., 2018) that are often a source of endogeneity and selection bias. The specification for each unit belonging to any group is given by:

$Y_{i t}=\beta_{0}+\beta_{1} I E T_{i t}+c_{i}+\theta_{t}+\varepsilon_{i t}$

Where $i$ represents a statistical individual and $t$ represents the year. In this study, statistical individuals are the indirectly treated or untreated companies that are observed over the 2008-2016 period. The parameter $\theta_{t}$ represents a dummy variable enabling the annual fixed effects to be taken into account, in particular the effects of financial crises, which can have an influence on corporate performance. This specification also includes the individual effect $c_{i}$ thus controlling for all unobservable characteristics within company that do not change over time but which may have an effect on the company's result variables. The introduction of this parameter is very useful because it partially addresses selection and endogeneity problems. This component could easily include the strategies of company, the intelligence of managers, the organisation mode of the company, etc. It is therefore assumed that these unobservable variables are stable over time and specific to each firm. $I E T_{i t}$ : represents the indirect effect of treatment. It is the treatment variable that takes the value 1 if the enterprise is part of the reference group, in year $t$ and 0 otherwise. $Y_{i t}$ : represents the outcome variables of the enterprise $i$ at time $t$. $\varepsilon_{i t}$ : a random disturbance term. $\beta_{1}$ : is our parameter of interest, it measures the average indirect effect of TRI on firm performance indicators.

The estimation procedure is a two-stage process. The first step is to estimate the propensity score based on the observable characteristics of companies in the base year. Since the Nanoelec TRI was established in 2012, we chose 2011 as the base year. This choice is guided by the evaluation literature where authors always choose the year before treatment as the reference year (see the work of Garone et al., 2014; Di Gennaro and Pellegrini, 2017; etc.). In the second step, we simply estimated equation (6) using the fixed-effects estimator to identify the average indirect effect of TRI on the financial and employment variables of small and medium-sized enterprises (SMEs). A distinction can be made between the permanent mean effect and the annual mean effect because the literature shows that indirect effects do not appear immediately after treatment but only a few years after treatment (see the work of Castillo et al. 2014).

\footnotetext{
${ }^{9}$ Conditional Independence Assumption

${ }^{10}$ Stable Unit Treatment Value Assumption
} 


\subsection{Data and outcome variables}

This empirical work uses panel data observed between 2008 and 2016 for financial variables and between 2008 and 2015 for employment variables. The choice of these study periods is justified by the availability of data. Our effect study is based on an original database from several data sources. The data relating to the beneficiary companies are collected by the Nanoelec TRI and completed by EuroLIO. ${ }^{11}$ They essentially contain information on company name, the identifier, the post code, the sector of activity (industry), the number of projects carried out by each company, the year in which the project started and ended, the amount paid per project and per company, etc. The financial and accounting data relating to beneficiary and non-beneficiary enterprises were obtained from the DIANE database. This is a database produced by Bureau van Dijk which collects general, financial and stock market information on French companies. The study also uses DADS data from INSEE. This contains information on employment (total number of employees, number of managers, information on employer, etc.). We also used the GECIR database which is produced by the Directorate General of Public Finance (DGFiP), and includes information on the amounts of the Research Tax Credit (RTC). By merging these different databases and sorting only for SMEs, we obtained an initial database of 2,306 potential indirect beneficiaries. The group of indirect beneficiaries is constituted by selecting from the 2,306 potential indirect beneficiaries, all the SMEs located in the Isère department (the treated department) which belong to the same industries as those of the Nanoelec TRI firms. In order to take into account, the cross-industry spillovers, we use two-digits standard industrial classification which represents the major industry sector to which a business belongs. We also control for some characteristics as age, research tax credit, financial variables (turnover, equity, financial autonomy), emplyoment variables (total employment, number of managers, share of managers). This operation resulted in a base of 90 indirect beneficiary companies.

Unlike most empirical studies (see Zuniga-Vicente, Alonso-Borrego, Forcadell and Galan 2014, Chai and Shih 2016, Ben Hassine and Mathieu 2017, Bellucci et al. 2018, etc.) which focus on innovation variables (R\&D expenditures, R\&D personnel, publications, patents, etc.) when the analysis is carried out in a short and medium term horizon, we focus on the socio-economic variables of SMEs. The choice of long-term variables when the analysis is carried out in the short and medium term is explained by the fact that the technological platforms are designed to accelerate the transfer of innovation to companies and consequently reduce the time of transition from $R \& D$ to industrial production and from production to the economic performance of companies. The outcome variables fall into two categories: financial variables (turnover, equity and financial autonomy) and employment variables (total employment, number of managers and proportion of managers). The turnover is the sum of a company's sales of goods or services over an accounting period. It gives an indication of the level of activity and allows comparisons and analysis in time and space. With regards to the financial resources owned by the company (excluding debt), equity is an interesting indicator. In particular, changes in equity make it possible to give an account of the development of company, but also of its financial health insofar as having a high level of equity capital limits the risk of bankruptcy. Financial autonomy is an indicator which determines the level of dependence of a company on external financing, in particular bank loans. It also makes it possible to assess debt capacity. This is measured by the ratio between equity and long-term financial debt. The higher this ratio, the more independent a firm is from its lenders. The total number of employees of a company is an interesting quantitative indicator that shows whether a TRI has an indirect effect on the number of people hired. The number of managers is an indicator that takes into account the quality of the job, while the proportion of managers (highly skilled employees) aims to capture changes in the structure of the job.

\section{Evaluation results}

This section presents the results of our analysis of the indirect effects of the technological platform in the shape of the Nanoelec TRI on SMEs performance, including matching results, difference-in-differences method results and robustness tests to corroborate the obtained results. Two types of indirect effects are estimated and presented in this section: permanent indirect effects and annual indirect effects. The permanent indirect effect measures the average indirect effect of the TRI over the whole period between 2012 and 2016, i.e., from the start of treatment (in 2012) until the end of data availability (2016). The annual indirect effect simply measures for each year from 2012, the indirect effect of the TRI on firms.

\footnotetext{
${ }^{11}$ European Observatory of Localised Data on Innovation
} 


\subsection{Selection of control firms: matching}

In order to take into account, the non-randomness of the treatment, matching is carried out at two levels: departmental and firm levels. At the departmental level, control departments were selected on the basis of a typology study of departments carried out by Eurolio (2018). On the basis of some thirty variables observed in 2011 making it possible to measure characteristics of the population, their qualifications and their lives including the economic and employment situation, regional characteristics (geographical location, agglomeration and attractiveness) and knowledge absorption capacity, the departments were classified using two classification methods, the hierarchical ascending classification and the mobile centre method. This made it possible to define four general profiles of the departments: "West Paris"; "metropolitan departments"; "intermediate departments" and "departments with predominantly productive and agricultural activities". Our treated department (Isère) belongs to the class of "metropolitan departments" which includes 16 other departments. Our 16 control departments are as follows : Alpes-Maritimes (6), Bouches-du-Rhône (13), Haute-Garonne (31), Gironde (33), Hérault (34), Loire-Atlantique (44), Nord (59), Pas-de-Calais (62), Bas-Rhin (67), Rhône (69), Seine-Maritime (76), Seine-et-Marne (77), Essonne (91), Seine-Saint-Denis (93), Val-de-Marne (94) and Val-d'Oise (95). In order to avoid the effect of a possible trans-departmental externality from the treated department that might affect control firms, we removed the neighbouring departments, in this case Rhône (69), and we selected all SMEs located in the remaining control departments. This operation led to the identification of 401 potential control firms. The distribution of these companies is presented in Table 2. The department numbers that do not appear in Table 2 are the departments for which no SME could be identified in our database.

Table 2: Distribution of control firms according to control departments

\begin{tabular}{|l|l|l|l|l|l|l|l|l|l|l|l|l|}
\hline $\begin{array}{l}\text { Department } \\
\text { code }\end{array}$ & 13 & 31 & 33 & 34 & 44 & 59 & 67 & 76 & 91 & 93 & 94 & Total \\
\hline $\begin{array}{l}\text { Number of } \\
\text { firms }\end{array}$ & 388 & 1 & 1 & 1 & 1 & 1 & 1 & 1 & 3 & 2 & 1 & 401 \\
\hline
\end{tabular}

It can be noticed that companies are unevenly spread across the control departments. More precisely, $97 \%$ of them are highly concentrated in the Bouches-du-Rhône department (13). The question that arises is whether the 401 companies can represent a valid control group. The answer to this question lies in Table 3 which presents the results of the comparison between the group of indirect beneficiaries and the potential control group. Analysis of this table clearly indicates that the group of 401 potential control firms cannot be used as a counterfactual group as it is statistically different from the reference group. Therefore, matching should be carried out in order to select from the 401 companies those that are statistically identical to the indirect beneficiaries. To do this, we used the closest neighbour matching method to construct the control group. It is very often recommended to select more than one control firm per indirect beneficiary firm. In this case, we select the three best comparison firms per indirect beneficiary firm. Therefore, for each indirect beneficiary, the three best control firm is simply selected, making a total sample of 270 firms (90 indirect beneficiaries and 180 control firms). The quality of the matching was assessed by means of the "balancing tests", which consist in comparing the characteristics and performance of the indirect beneficiary firms with the control firms before and after matching (see Table 3 and Table 4).

Table 4 presents the results of the comparison between the indirect beneficiary firms and the control firms after matching. Tests of difference in means/proportions show that the two groups are significantly identical across all characteristics and outcome variables. These results suggest that the matching is of good quality. 
Table 3: Comparison between the indirect beneficiaries' group and the potential control group prior to matching (2011)

\begin{tabular}{|c|c|c|c|}
\hline & $\begin{array}{l}\text { Indirect beneficiaries' } \\
\text { firms }\end{array}$ & Potential control firms & \\
\hline Characteristics & Mean/ proportion & Mean/proportion & Test of difference \\
\hline Turnover & $3,401,237$ & $1,847,885$ & $1,553,352 * * *$ \\
\hline Equity & 892,972 & 644,292 & 248,680 \\
\hline Financial autonomy & 33.55 & 21.66 & $11.88^{* * *}$ \\
\hline Total employment & 24.4 & 15.16 & $9.24 * * *$ \\
\hline Number of managers & 4.6 & 3.3 & 1.33 \\
\hline Proportion of managers & 0.16 & 0.143 & 0.025 \\
\hline Proportion of RTC firms & 0.177 & 0.114 & 0.063 \\
\hline Research Tax Credit (RTC) & 444,263 & 86,557 & $-7,577$ \\
\hline Age & 21.7 & 19.32 & 0.81 \\
\hline \multicolumn{4}{|l|}{ Typology } \\
\hline Very small firms & 0.245 & 0.66 & $-0.42 * * *$ \\
\hline Small and medium firms & 0.755 & 0.44 & $0.42 * * *$ \\
\hline \multicolumn{4}{|l|}{ Industries } \\
\hline Most representative industries & 0.8 & 0.67 & $0.13 * *$ \\
\hline Least representative industries & 0.2 & 0.33 & $-0.13 * *$ \\
\hline Number of companies & 90 & 401 & Total $=491$ \\
\hline
\end{tabular}

Notes : The signs $* * *, * *$ and $*$ correspond respectively to the statistically significant coefficients at $1 \%, 5 \%$ and $10 \%$. 
Table 4: Comparison between the indirect beneficiaries' group and the control group after matching

\begin{tabular}{|c|c|c|c|}
\hline & $\begin{array}{l}\text { Indirect beneficiaries' } \\
\text { firms }\end{array}$ & Control firms & \\
\hline Characteristics & Mean/ proportion & Mean/proportion & Test of difference \\
\hline Turnover & $3,401,237$ & $3,568,695$ & $-167,458$ \\
\hline Equity & 892,972 & 827,810 & 65,162 \\
\hline Financial autonomy & 33.55 & 27.88 & 5.66 \\
\hline Total employment & 24.4 & 28.44 & -4.04 \\
\hline Number of managers & 4.6 & 6.56 & -1.93 \\
\hline Proportion of managers & 0.16 & 0.78 & -0.612 \\
\hline Proportion of RTC firms & 0.177 & 0.183 & -0.006 \\
\hline Research Tax Credit (RTC) & 78,980 & 182,016 & $-103,036$ \\
\hline Age & 21.7 & 20.62 & 1.11 \\
\hline \multicolumn{4}{|l|}{ Typology } \\
\hline Very small firms & 0.245 & 0.273 & -0.028 \\
\hline Small medium firms & 0.755 & 0.727 & 0.028 \\
\hline \multicolumn{4}{|l|}{ Industries } \\
\hline Most representative industries & 0.8 & 0.8 & 0 \\
\hline Least representative industries & 0.2 & 0.2 & 0 \\
\hline Number of companies & 90 & 180 & Total $=270$ \\
\hline
\end{tabular}

Notes: The signs $* * *, * *$ and $*$ correspond respectively to the statistically significant coefficients at $1 \%, 5 \%$ and $10 \%$.

\subsection{Permanent indirect effect on the performance of non-beneficiary SMEs}

The analytical results of the permanent indirect effect of the TRI are presented in Table 5. For each performance indicator, we present the number of observations, the number of indirect beneficiaries, the number of counterfactual (control) firms and the estimated permanent indirect effect.

The analysis of results indicates that the Nanoelec TRI has positive effects on the financial variables and no effect on the employment variables of the indirect beneficiaries (see Table 5). Regarding financial variables, the estimates show the presence of a positive and significant spillover effect on the turnover and financial autonomy of SMEs. More specifically, the turnover and financial autonomy of the firms located in the Isère department increased by EUR 449,047 and EUR 2.782 respectively, compared with the firms located in the control departments. In other words, firms benefit from positive spillover effects in terms of turnover and financial autonomy, due to their geographical and industry proximity to the Nanoelec TRI and local firms. This suggests that the concentration of activities and the Nanoelec TRI infrastructure generates the positive spillover effects that benefit the untreated firms located in the treated department. These results seem to be in line with one of the foundations of science-industry-type innovation policies, which is to generate positive effects beyond the direct 
beneficiaries to reach the indirect beneficiaries. On the other hand, there is an insignificant and negative indirect effect on equity. This could be explained by competitive effects on capital inflows between beneficiaries and non-beneficiaries. The results on sales seem to be consistent with the literature, in particular with the work of Nishimura and Okamuro (2016) who found an additional indirect effect on the sale of innovative products and other performance indicators, namely labour productivity and total factor productivity.

As for employment variables, no significant indirect effect is found in this study. However, there is a nonsignificant positive effect on the proportion of managers. This result could be explained by the fact that the time period is not long enough to observe the effects. The effects on employment variables are generally observed over the long-term. In the study by Castillo et al. (2014), the authors identified an indirect causal effect on employment and wages with a fairly large time lag of about 15 years (1995-2010). It should be noted that the absence of permanent effects on employment variables in this study does not mean that there are no effects. There could be an annual effect, which is why it would be interesting to see how this effect breaks down annually.

The robustness of all these results were conducted in two ways: In the first way, common trend hypothesis ${ }^{12}$ was carried out (see results in appendix Table 7 ) and in the second way, another group of control constructed by another matching method was used to estimate the indirect effects. The robustness has confirmed the findings (see appendix Table 8).

Table 5: Permanent indirect effect of the TRI on SME Performance - Summary of the results of the indirect effect evaluation

\begin{tabular}{|l|l|l|l|}
\hline Outcome variables & & Outcome variables & \\
\hline Financial variables & Estimated effects & Employment variables & Estimated effects \\
\hline Turnover & & Total employment & \\
\hline Permanent mean effect & $\begin{array}{l}449,047^{* * *} \\
(172,825)\end{array}$ & Permanent mean effect & -0.198 \\
& & Number of managers & \\
\hline Equity & $-29,832$ & & \\
\hline Permanent mean effect & $(90,779)$ & Permanent mean effect & -0.079 \\
& & Share of managers & $(0.313)$ \\
\hline Financial autonomy & $2.782 *$ & Permanent mean effect & 0.005 \\
\hline Permanent mean effect & $(1.446)$ & & $20.01)$ \\
\hline Study period & $2008-2016$ & & $2008-2015$ \\
\hline Number of observations & 2430 & & $84 / 168$ \\
\hline Number of treated/controls & $90 / 180$ & & \\
\hline
\end{tabular}

Notes: The signs $* * *, * *$ and $*$ correspond respectively to the statistically significant coefficients at $1 \%, 5 \%$ and $10 \%$. Standard errors in parentheses are robust to both heteroscedasticity and autocorrelation.

\footnotetext{
${ }^{12}$ For more explanation, see sub-section 1.1 in appendix
} 


\subsection{Annual indirect effect on the performance of non-beneficiary SMEs}

The estimation results obtained show the presence of local spillover effects (see Table 6). Columns 1 to 5 represent the 2012 to 2016 respectively. The estimated annual effects are limited to 2015 for the employment variables due to data unavailability. This explains the difference in the number of observations between employment and financial variables.

For the financial variables, it should be noticed that the annual effects remain focused on the same performance indicators as the permanent effects. The estimation results seem to indicate the presence of local spillover effects that positively affect the turnover and financial autonomy of SMEs. In other words, the Nanoelec TRI has an additional effect on the turnover and financial autonomy of SMEs that are not beneficiaries of TRI actions but are located close to it. Moreover, the dynamics of the effects show that these indirect effects are focused on 2015 and 2016 for turnover and only on 2016 for financial autonomy. This means that the indirect effects do not appear directly after treatment (Castillo et al., 2014). More specifically, the untreated firms located in Isère (i.e. the indirect beneficiary firms) saw their turnover increase significantly, by EUR 458,262 and EUR 525,061 corresponding to 2015 and 2016 respectively, compared with the control firms located in the control departments. Similarly, the untreated companies located in Isère saw their financial autonomy increase significantly by 4,944 in 2015, compared to the control companies located in the control departments. Moreover, we also note that these effects tended to increase from 2015, which is good news for the TRI policy insofar as the effects not only persist over time but also increase in magnitude. Furthermore, the results on annual effects suggest that the permanent effect found on turnover is strongly influenced by the annual effects of 2015 and 2016, while the effect on financial autonomy is only influenced by the annual effect of 2016 .

Concerning the employment variables, the dynamic is a little more complex. Unlike the results on permanent effect, a negative indirect effect in 2012 (treatment year) can be observed on the proportion of managers and a positive indirect effect on the same variable in 2015. More precisely, the TRI had a negative indirect effect of 0.025 on the proportion of managers during the first year of treatment and then a positive indirect effect of 0.019 in 2015 on the same variable. On the other hand, no significant indirect effect is identified for total employment and the number of managers. The analysis of the dynamics confirms a time lag in the appearance of the indirect effects. This time lag could be explained by the fact that the transmission of knowledge from treated firms to untreated firms requires interactions between firms, which take time.

The robustness of all these results were conducted in two ways: In the first way, common trend hypothesis was carried out (see results in appendix Table 7 ) and in the second way, another group of control constructed by another matching method was used to estimate the indirect effects. The robustness has confirmed the findings (see appendix Table 9). 
Table 6: Indirect annual effect of the Nanoelec TRI

\begin{tabular}{|c|c|c|c|c|c|}
\hline & $\begin{array}{c}(1) \\
2012\end{array}$ & $\begin{array}{c}(2) \\
2013\end{array}$ & $\begin{array}{c}(3) \\
2014\end{array}$ & $\begin{array}{c}(4) \\
2015\end{array}$ & $\begin{array}{c}5) \\
2016\end{array}$ \\
\hline \multicolumn{6}{|c|}{ Financial variables } \\
\hline \multicolumn{6}{|l|}{ Turnover } \\
\hline Annual effects & $\begin{array}{l}43,779 \\
(145,661)\end{array}$ & $\begin{array}{l}-4,602 \\
(138,196)\end{array}$ & $\begin{array}{l}100,118 \\
(190,197)\end{array}$ & $\begin{array}{l}458,262 * \\
(238,417)\end{array}$ & $\begin{array}{l}525,061 * \\
(299,125)\end{array}$ \\
\hline \multicolumn{6}{|l|}{ Equity } \\
\hline Annual effects & $\begin{array}{l}14,041 \\
(67,265)\end{array}$ & $\begin{array}{l}-8,392 \\
(84,476)\end{array}$ & $\begin{array}{l}-58,678 \\
(107,109)\end{array}$ & $\begin{array}{l}-15,509 \\
(117,045)\end{array}$ & $\begin{array}{l}-6,043 \\
(145,736)\end{array}$ \\
\hline \multicolumn{6}{|l|}{ Financial autonomy } \\
\hline Annual effects & $\begin{array}{l}-1.401 \\
(1.522)\end{array}$ & $\begin{array}{l}-0.288 \\
(1.488)\end{array}$ & $\begin{array}{l}1.337 \\
(1.77)\end{array}$ & $\begin{array}{l}2.364 \\
(1.932)\end{array}$ & $\begin{array}{l}4.944 * \\
(2.64)\end{array}$ \\
\hline Nb. of observations & 2430 & 2430 & 2430 & 2430 & 2430 \\
\hline \multicolumn{6}{|c|}{ Employment variables } \\
\hline \multicolumn{6}{|l|}{ Total employment } \\
\hline Annual effects & $\begin{array}{l}-0.487 \\
(1.044) \\
\end{array}$ & $\begin{array}{l}0.438 \\
(0.999) \\
\end{array}$ & $\begin{array}{l}-0.181 \\
(1.183) \\
\end{array}$ & $\begin{array}{l}-0.222 \\
(1.156) \\
\end{array}$ & - \\
\hline Number of managers & & & & & - \\
\hline Annual effects & $\begin{array}{l}-0.29 \\
(0.353)\end{array}$ & $\begin{array}{l}0.247 \\
(0.342)\end{array}$ & $\begin{array}{l}-0.297 \\
(0.429)\end{array}$ & $\begin{array}{l}0.159 \\
(0.452)\end{array}$ & - \\
\hline Proportion of managers & & & & & - \\
\hline Annual effects & $\begin{array}{l}-0.025^{* *} \\
(0.011) \\
\end{array}$ & $\begin{array}{l}0.009 \\
(0.011) \\
\end{array}$ & $\begin{array}{l}0.008 \\
(0.011) \\
\end{array}$ & $\begin{array}{l}0.019 * \\
(0.012)\end{array}$ & - \\
\hline $\mathrm{Nb}$. of observations & 2016 & 2016 & 2016 & 2016 & - \\
\hline
\end{tabular}

Notes: The signs ***, ** and * correspond respectively to the statistically significant coefficients at $1 \%, 5 \%$ and $10 \%$. Standard errors in parentheses are robust to both heteroscedasticity and autocorrelation.

\section{Explanations and implications}

\subsection{Explanations}

The main research question was whether firms that did not participate in the Nanoelec TRI still improved their performance as a result of their linkages with participating firms. In other words, the aim was to estimate the indirect effects of the Nanoelec TRI on the performance of non-treated firms. Two types of indirect effects were estimated: The permanent indirect effect that measures the average indirect effect of the TRI over the whole period 2012 - 2016, i.e. from the start of treatment (in 2012) until the end of data availability (2016). The annual indirect effect which simply measures, for each year from 2012 onwards, the indirect effect of the TRI on firms. Two groups of outcome variables were used: financial variables (turnover, equity and financial autonomy) and employment variables (total employment, number of managers and proportion of managers).

The main results show that the Nanoelec TRI has a permanent indirect effect on non-beneficiary companies. Specifically, despite their non-participation in the TRI, they have significantly improved their financial performance in terms of turnover and financial self-sufficiency through their linkages with the participating companies. This result appears to be consistent with the literature which has explained that non-participating firms may improve certain financial performance indicators due to business linkages with participating firms (see subsection 2.1.2 Indirect effects via customer-supplier links). For the employment variables, no permanent 
indirect effects are identified. This result could be explained by the fact that the period is not long enough to observe the effects.

The estimation of the annual indirect effects confirms the significant effects on the same financial performance variables but shows that these effects do not appear immediately after treatment, which is consistent with the literature on the dynamics of indirect effects. With respect to the employment variables, the results show that the dynamics are somewhat complex in that there is a negative effect on the share of managers in 2012 (the year of the start of treatment) and a positive effect in 2015 on the same variable. Analysis of the dynamics confirms a lag in the appearance of indirect effects. The negative effect seems consistent with the theoretical literature and could therefore be explained by the market distortion (see sub-section 2.1.3. Indirect effects via the skilled labour market), which is due to the fact that treated local firms hire more skilled workers (because they are supported) to the detriment of untreated local firms, which will find it difficult to gain access to skilled labour that was already expensive before the policies were put in place.

\subsection{Implications}

The implications of the results can be summarized at two levels: at the level of public innovation policy design and at the level of evaluation of public innovation policies. With respect to the design of innovation policies, the results suggest that even firms that did not participate in the policy could still benefit from the spillovers of this policy as long as they have geographical and technological proximities with the beneficiary firms. Our results also suggest that these benefits could be explained by the different links that would exist between beneficiaries and non-beneficiaries. In this context, it would be interesting to take this element into account in the design of a place-based innovation policy. More specifically, it would be important to incorporate into the policy, mechanisms or devices that are likely to facilitate interactions between beneficiaries and non-beneficiaries firms. This would allow spillovers to diffuse more easily and affect non-treated firms more quickly.

In terms of evaluating public policy in general and public policy in the field of innovation in particular, it would be interesting when it comes to evaluating the effect of a policy, measuring both effects of this policy on both beneficiaries and non-beneficiaries. The challenges of not taking non-beneficiaries into account are important. According to Angelucci and Maro (2015), ignoring indirect effects or spillovers during evaluation will lead to biased estimates of the effect of the policy. According to these authors, one of the direct consequences of a biased effect evaluation is to provide false conclusions and, in turn, to make erroneous policy recommendations. Another consequence they underline is "the incomprehension of the models of data generation". In other words, it would be difficult to understand the extent of the real effect of the policy. In this context, the evaluation of the indirect effects of a policy becomes essential for political decision-makers insofar as it could allow them to better understand the real effect of the policy, to measure the total effect (direct + indirect) of policy, to compare the two types of effects (direct and indirect), to better understand the extent of the policy on the local economy and to better understand the reaction of the economy local to a policy. In addition, the growing interest in indirect effects is not limited to government. In fact, raising awareness and estimating indirect effects has become a central pillar of causal analysis and policy evaluation in the sense that including indirect effects in the traditional framework is not simple and can still be considered one of the main challenges facing researchers (Di Gennaro and Pellegrini, 2017).

\section{Conclusion}

The objective of this paper was to analyse and evaluate the indirect causal effect of place-based science-industry transfer policies. More specifically, the effect of the presence of local spillover effects of technological platforms on the financial and employment variables of non-treated small and medium-sized enterprises (SMEs) is examined and assessed. For this purpose, we considered the French Technological Research Institute (TRI) known as Nanoelec, which is a thematic interdisciplinary institute based on technological platforms which aims to generate positive spillovers so that they can benefit companies that are not direct beneficiaries of the device. We define an indirect effect as the effect of treatment on non-beneficiaries. In this study, we hypothesise that the indirect effects are localised in the "Isère" department, where the Nanoelec TRI is located. Two main research questions are addressed in this study. The first seeks to determine whether the TRI had additionality effects on the financial and employment variables of non-beneficiary SMEs located in Isère. The second examines the 
evolution of indirect effects over time. In other words, this paper seeks to know whether these effects are specific to years or whether they are permanent?

This issue was approached by comparing local non-beneficiary firms with non-beneficiary firms located in the control departments in order to control for all unobservable variables at the level of the departments that could affect the outcome variables. Using a matched difference-in-differences approach to panel data observed over the 2008-2016 period, results tend to provide empirical evidence of the local spillover effects on both financial and employment variables. In other words, the estimates show that the TRI has had additional effects on the financial and employment variables of local non-treated SMEs. Regarding the financial variables, the TRI was successful in generating local spillover effects that positively affected the turnover and financial autonomy of local nontreated SMEs compared to non-local control SMEs. In terms of employment variables, the spillovers generated by the TRI negatively affected the proportion of managers at the beginning of the treatment (the creation of the TRI) and then positively affected it few years later.

By distinguishing permanent effects from annual effects, our estimates suggest that the TRI has a permanent and annual effect on turnover and financial autonomy and that annual effect seems to be focused on 2015 and 2016. On the other hand, there is only a positive annual effect on the proportion of managers, which remains focused in 2015. Moreover, the analysis of the dynamics of these effects shows that they do not appear immediately after the treatment, as underlined by Castillo et al. (2014), but emerge a few years later. This time lag could be explained by the time needed for non-beneficiaries' companies to interact with beneficiaries companies or to assimilate the knowledge in their environment. These results seem to be consistent with some findings in the empirical literature (see the work of Nishimura and Okamuro 2016; Castillo et al. 2014; Di Gennaro and Pellegrini 2017) in which significant indirect effects can be found even though the channels of transmission of the effects are not identical.

This work makes two contributions. The first contribution of this paper is methodological in the sense that it proposes a method for evaluating indirect effects through an original construction of a counterfactual of indirect beneficiaries in order to measure these effects. Indeed, the principles of counterfactual evaluation are based on the fundamental hypothesis of the absence of spillovers (positive or negative). This is a very strong assumption insofar as in an economy, beneficiary firms cannot be isolated from the rest of the non-beneficiary firms. Consequently, there is a strong interest in taking spillovers into account in the evaluation of a policy by relaxing this assumption. This article contributes towards relaxing that assumption. The second contribution is in terms of the evaluation of innovation policies based on science-industry relations. Indeed, one of the foundations of this category of innovation policies is to generate knowledge spillovers that are sufficiently high to benefit firms that are not directly beneficiaries. Despite the scale of this policy, only one empirical study (Nishimura and Okamuro, 2016) to our knowledge has sought to evaluate the indirect effects of these policies. This study fills this gap.

This study could be interesting for policy-makers and therefore requires some recommendations. The first recommendation concerns the role of local spillover effects. Our effect assessment highlighted the positive effects of local spillover effects on business performance. Therefore, it would be interesting for policy makers to take spillover effects into account as an essential element in policy design. Moreover, the positive effects of local spillovers tend to suggest that this positive effect could be the result of interactions between direct beneficiairies and non-beneficiary firms. Therefore, policymakers could improve policy design by focusing on facilitating local interactions between firms. This is equivalent to considering that there is a relationship between the spatial distribution of the policy and the objectives of the policy. Indeed, if the policy aims at maximising the benefits to direct beneficiary firms, then it would be interesting to adopt a dispersed distribution of treatment. On the other hand, if the public authorities seek to optimise the effects on all the firms located in a region, then it would be preferable to adopt a concentrated distribution of the treatment (Di Gennaro and Pellegrini, 2017).

This study raises several potential avenues for research. Firstly, the study mainly focuses on geographical distance to define and establish the indirect beneficiary firms. However, geographical distance is a black box that encompasses other important elements such as social networks, which could be at the origin of the observed effects on company performance. In other words, the question that arises is whether the observed effects are solely the result of geographical proximity or whether they are the result of other proximities, particularly social or commercial proximities, which are "drowned" in spatial distance. It would be interesting to explore this question in future research. More precisely, it would be interesting to explore each way by which the indirect effects occur in order to check which of three ways (see section 2.1.) could predominate. This could better help in designing the policy. For instance, for the commercial proximity, one could constitute the indirect beneficiaries by selecting all the clients and suppliers of direct beneficiaries and check if the policy has indirectly 
affected these categories of firms. In this case, the difficulty would be to get information about the clients and suppliers because of their confidentiality. For the social proximity, it would be interesting to constitute the indirect beneficiaries through the network analysis by exploiting collaborations (co-patenting, co-publications, etc.). Secondly, this evaluation study relies mainly on the additionality of socio-economic variables. These variables may not be sufficient to assess the effectiveness of place-based science-industry transfer policies. Some authors such as Bellucci et al. (2018), suggest that outcome variables should be identified to better analyse and assess behavioural additionality. It would therefore be interesting to investigate further from this perspective. This would involve examining whether the TRI has indirectly influenced the R\&D strategy of firms (SMEs), and more particularly whether it has improved their ability to collaborate with other firms and research centres in and outside the TRI; whether firms collaborate more on R\&D projects; whether there is an intensification of existing partnerships; and whether treated firms have launched riskier, high-potential R\&D projects (see OECD, 2006). Thirdly, this study focuses only on the Nanoelec TRI, which means that the results cannot be generalised. Therefore, it would be important to evaluate the indirect effects of the six other TRIs established in France in order to have a comprehensive view of the effectiveness of the TRI policy and to be able to develop interpretation of the heterogeneous effectiveness of the different ways that have been chosen to implement the TRIs.

\section{Reference}

Angelucci, M., \& Maro, V. D. (2015). Program evaluation and spillover effects. Policy Research Working Paper Series 7243, World Bank.

ANR. (2010). Investissement d'avenir: Instituts de recherche technologique. Agence Nationale de la Recherche, Edition 2010.

Arrow, K. (1962). The rate and direction of inventive activity : Economic and social factors. In (p. 609 - 626). Princeton University Press.

Anselin, L., Varga, A., \& Acs, Z. (1997). Local geographic spillovers between university research and high technology innovations. Journal of urban economics, 42(3), 422-448.

Asheim, B. T., \& Isaksen, A. (2002). Regional innovation systems: The integration of local 'sticky' and global 'ubiquitous' knowledge. The Journal of Technology Transfer, 27(1), 77-86.

Autant-Bernard, C., \& Massard, N. (2004). Disparités locales dans la production d'innovation : l'incidence du choix des indicateurs. Mimeo, Quatrièmes Journées de la Proximité ‘Proximité, réseaux et coordination’.

Barbesol, Y., \& Briant, A. (2008). Économies d'agglomération et productivité des entreprises : estimation sur données individuelles françaises. Economie et statistique (n²419-420), pp. 31-54.

Bartel, A., \& Lichtenberg, F. (1987). The comparative advantage of educated workers in implementing new technology. The Review of Economics and Statistics.

Bellucci, A., Zazzaro, A., \& Pennacchio, L. (2018). Public R\&D subsidies: collaborative versus individual placebased programs for smes. Small Business Economics.

Ben Hassine, H., \& Mathieu, C. (2017). Évaluation de la politique des pôles de compétitivité : la fin d'une malédiction? Document de travail France Stratégie.

Brossard, O., \& Moussa, I. (2014). The French cluster policy put to the test with differences-in-differences estimates. Economics Bulletin, 34(1), 520-529.

Buisseret, T., Cameron, H., \& Georghiou, L. (1995). What difference does it make? additionality in the public support of $\mathrm{r} \& \mathrm{~d}$ in large firms. International Journal of Technology Management, 10, 587-600. doi: https://doi.org/10.1504/IJTM.1995.025644 
Castillo, V., Maffioli, A., Rojo, S., \& Stucchi, R. (2014). Knowledge spillovers of innovation policy through labor mobility: An impact evaluation of the fontar program in Argentina. Inter-American Development Bank: Office of Strategic Planning and Development Effectiveness.

Chai, S., \& Shih, W. (2016). Bridging science and technology through academic-industry partnerships. Research Policy, 45(1), 148-58. doi: 10.1016/j.respol.2015.07.007

Cockburn, I., \& Henderson, R. (1998). Absorptive capacity, co-authoring behavior, and the organization of research in drug discovery. The Journal of Industrial Economics, vol. XLVI (2), 157-181.

Ciccone, A., \& Hall, R. (1996). Productivity and the density of economic activity. American Economic Review, 86(1), 54-70.

Cohen, W. M., \& Levinthal, D. A. (1989). Innovation and learning: the two faces of R\&D. Economic Journal (99), 569-596.

Crespi, G., Criscuolo, C., Haskel, J., \& Slaughter, M. (2008). Productivity growth, knowledge flows and spillovers. National Bureau of Economic Research.

Davenport, T. (2005). Thinking for a living: how to get better performance and results from knowledge workers. Harvard Business School Publishing, Boston.

Dessertine, M. (2014). Pôles de compétitivité et emploi ? : une analyse microéconomique de l'effet des coopérations en R\&D (Thèse de doctorat non publiée). Université Jean Monnet - Saint-Etienne.

Di Gennaro, D., \& Pellegrini, G. (2017). Evaluating direct and indirect treatment effects in italian r\&d expenditures. University Library of Munich, Germany.

Dujardin, C., Louis, V., \& Mayneris, F. (2015). Les pôles de compétitivité wallons quel impact sur les performances économiques des entreprises ? The Walloon competitiveness clusters and their impact on firms' economic performances? IRES Discussion papers.

Duranton, G., \& Puga, D. (2004). Micro-foundations of urban agglomeration economies. in J.V. Henderson and J.-F. Thisse, eds., Handbook of Urban and Regional Economics, 4.

Eurolio. (2018). Impacts macro-territoriaux : Effets départementaux différenciés de l'adhésion aux pôles et du ciblage stratégique des secteurs. Working paper, Eurolio.

Ellison, G., Glaeser, E., \& Kerr, W. (2010). What causes industry agglomeration? Evidence from coagglomeration patterns. American Economic Review, 100(3), 1195-1213.

Etzkowitz, H., \& Leydesdorff, L. (2000). The dynamics of innovation : from national systems and "mode 2" to triple helix of university-industry-government relations. Research Policy, 29(2), 109-123.

France-Stratégie. (2018). Renforcer le transfert de savoir entre la science et l'industrie : nouveaux dispositifs publics et pratiques d'entreprise. France Stratégie.

Gallié, E. P. (2004). Coopération, externalités de connaissance et géographie de l'innovation : Le cas du secteur des biotechnologies en France. Paris 1.

Garone, L. F., Maffioli, A., Rodriguez, C. M., \& De Negri, J. A. (2014). Cluster development policy, SME’s performance, and spillovers: evidence from brazil. Small Business Economics, 4, 925-948.

Gertler, P., Martinez, S., Premand, P., Rawlings, R. B., \& Vermeersch, C. M. J. (2011). Impact evaluation in practice. Washington. DC: World Bank.

Goto, A., \& Suzuki, K. (1989). R\&d capital rate of return on r\&d investment and spillover of $\mathrm{r} \& \mathrm{~d}$ in Japanese manufacturing industries. Review of Economics and Statistics, 74(1), 555-64.

Griliches, Z. (1979). Issues in assessing the contribution of research and development to productivity growth. The Bell Journal Economics, 10. 
Guellec, D. (1996). Knowledge, skills and growth: Some economic issues. STI Review, 18, 17-38.

Guellec, D., \& Van Pottelsberghe, B. (2000). The impact of public R\&D expenditure on business r\&d. OECD Science, Technology and Industry Working Papers ( $\left.n^{\circ} 2000 / 4\right)$.

Harding, C. F. (1989). Location choices for research labs: A case study approach. Economic Development Quarterly, 223-234.

Löfsten, H., \& Lindelöf, P. (2001). Science parks in Sweden industrial renewal and development? R\&D Management, 31(3), 309-322.

Lucas, R. (1988). On the mechanics of economic development. Journal of Monetary Theory.

Lundmark, M., \& Power, D. (2008). Handbook of research on innovation and clusters. Labour Market Dynamics and the Development of the ICT Cluster in the Stockholm Region, 208-221.

Lundvall, B. A. (1992). National systems of innovation: towards a theory of innovation and interactive learning. London. Pinter Publishers. doi: https://doi.org/10.1080/ 08109029308629360

Malecki, E. (1986). Research and development and the geography of high-technology complexes. in Technology, Regions and Policy (J. Rees, ed.), Rowman and Littlefield, Totowa.

Marshall, A. (1920). The principles of economics. Macmillan. Malecki, E. (1991). Technology and economic development. Longman Scientific and Technical, Essex.

March, J. G. (1991). Exploration and exploitation in organizational learning. Organization Science, 2(1).

Massard, N., \& Riou, S. (2003). L’agglomération de la recherche dans les départements français : une étude sur les années 1990. Économie et Sociétés (7), 607-631.

Madiès, T., \& Prager, J.-C. (2008). Innovation et compétitivité des régions (Rapport technique). Paris: Conseil d'analyse économique.

Mangematin, V., \& Nesta, L. (1999). What kind of knowledge can a firm absorb? International Journal of Technology Management.

Mowery, D. C., \& Sampat, B. N. (2007). Universities in national innovations systems. In : Fagerberg, J. Mowery \& D. Nelson, R. (Eds.)The Oxford Handbook of innovation. New York : Oxford University Press.

Nelson, R. (1986). Institutions supporting technical advance in industry. American Economic Review, 186-189.

Nishimura, J., \& Okamuro, H. (2016). Knowledge and rent spillovers through government sponsored r\&d consortia. Science and Public Policy, 43(2), 207-225. doi: https:// doi.org/10.1093/scipol/scv028/

OCDE. (2006). Government R\&D funding and company behaviour, measuring behavioural additionality. OCDE

Oerlemans, L.A., Meeus, M.T., \& Boekema, F.W. (2001). Firm clustering and innovation: determinants and effects. Conference "The future of innovation studies".

Rothwell, R., \& Dodgson, M. (1991). External linkages and innovation in small and medium-sized enterprises. R\&D Management, 21, 125-137.

Sveikauskas, L. (1975). The productivity of cities. The Quarterly Journal of Economics, 89(3), 393-413.

Shefer, D. (1973). Localization economies in SMA's: A production function analysis. Journal of Regional Science, 13(1), 55-65.

Terleckyj, N.E. (1974). Effects of R\&D on the productivity growth of industries: an exploratory study. Washington: National Planning Association.

Tushman, M., \& Katz, R. (1980). External communication and project performance: An 23 investigation into the role of gatekeepers. Management Science, 26(1), 1071-1085. 
U., Akcigit, D., Hanley \& N., Serrano-Velarde (2020). Back to basics: Basic research spillovers, innovation policy and growth. National Bureau of Economic Research Working Paper Series.

Zepeda, D. (2015). Propensity score matching: A primer in r. Center for Health Policy and Healthcare Research Brown Bag Series.

Zucker, L., Darby, M., \& Armstrong, J. (1994). Intellectual capital and the firm: the technology of geographically localised knowledge spillovers. WP NBER.

Zuniga-Vicente, J. A., Alonso-Borrego, C., Forcadell, F.-J., \& Galan, J. I. (2014). Assessing the effect of public subsidies on firms' R\&D investment: a survey. Journal of Economic Surveys, 28(1), 36-67. doi: https://doi.org/10.1111/j.1467-6419.2012.00738.x.

\section{Appendix}

\section{Robustness checks}

1.1. Testing the common trends hypothesis

The difference-in-differences method is based on the fundamental assumption of common trends the nonverification of which could discredit the estimation results. It is, therefore, essential to check this assumption in order to test the robustness of the results. The common-trends hypothesis states that, in the absence of the programme, the results in the treatment group would have followed the same trend as the results in the control group. In other words, results are expected to increase or decrease at the same rate in both groups. If the trends in outcomes are different between the two groups, then the estimates provided by the double difference method would be biased. In order to test this hypothesis, it is often recommended that the trends in the outcome variables in the treatment and control groups be tested a few years prior to the programme. For example, if it turns out that the two trends are parallel, then it could be inferred that, in the absence of the treatment, outcomes in the treatment group would have followed the same trend as outcomes in the control group. This could be done graphically or statistically. In this study, we chose the second option, following the recommendation from Gertler et al. (2011) who suggested that the validity of this hypothesis can be assessed by comparing changes in outcome variables for the treatment and control groups in the years prior to the programme. In our context, the Nanoelec TRI began in 2012, so we used data from 2008, 2009, 2010 and 2011 to calculate changes in outcome variables. Subsequently, we conducted a mean difference test to compare the changes in the outcome variables for the two groups.

The results of this test are summarized in Table 6. The results show that prior to the actual creation of the Nanoelec TRI, changes in the different outcome variables were not significantly different between the treatment and control groups. This is because the difference tests for each of the outcome variables are all insignificant, meaning that the null hypothesis that the changes in the outcome variables are the same in the two groups (treatment and control) prior to treatment is accepted. Furthermore, our results show that we can probably rule out the presence of an "Ashenfelter's Dip" effect in our sample. This is typically observed when programme participants abruptly change their pre-programme behaviours to the extent that pre-treatment values of the outcome variables vary. This phenomenon is often observed in programmes where participation is based on a number of criteria. If this phenomenon is not controlled for, then the estimated treatment effect is likely to be biased. In our case study, if there were an "Ashenfelter's Dip" effect, the trends for these outcomes would be different in the two groups of firms.

Table 7: Testing the common trends hypothesis

\begin{tabular}{|l|l|l|l|}
\hline & Indirect treated firms & Control firms & Test of difference \\
\hline Outcome variables & Mean of the variations & $\begin{array}{l}\text { Mean of the } \\
\text { variations }\end{array}$ & P-value \\
\hline \multicolumn{2}{|c|}{ Financial variables } \\
\hline
\end{tabular}




\begin{tabular}{|l|l|l|l|l|l|}
\hline Turnover & 237,119 & 197,339 & 39,780 & 0.6656 \\
\hline Equity & 65,841 & 35,126 & 30,715 & 0.3196 \\
\hline Financial autonomy & 0.757 & 0.509 & 0.248 & 0.7838 \\
\hline \multicolumn{2}{|c|}{ Employment variables } & -0.645 & 0.1025 \\
\hline Total employment & -0.288 & 0.357 & -0.317 & 0.1828 \\
\hline $\begin{array}{l}\text { Number of managers } \\
\text { Proportion of } \\
\text { managers }\end{array}$ & -0.236 & 0.081 & -0.0007 & 0.9376 \\
\hline
\end{tabular}

\subsection{Using a different control group constructed with a different matching method}

The results obtained using the counterfactual approach are regularly influenced by the control group used. This assumes that different estimation results can be obtained using different control groups. Therefore, it is important to test the robustness of the estimation results by using another control group constructed through another matching method. Thus, the effect evaluation is robust if the estimated effects with another control group are similar to those obtained with the original control group. In this study, we used the optimal matching method to construct a new control group. This matching method selects the control units and matches them to the treated units on the basis of the smallest mean absolute distance (Zepeda, 2015). With this method, we selected the two best control firms, resulting in a sample of 270 firms, of which 180 were control firms. We replicated the same analyses. Overall, the results pooled in Tables 7 and 8 are very close. This therefore assumes that the two results obtained from two different control groups are stable. We can therefore conclude that our results are robust.

Table 8: The permanent indirect effect of the TRI on SME Performance - summary of the results of the indirect effect evaluation (with another control group).

\begin{tabular}{|l|l|l|l|}
\hline Outcome variables & & Outcome variables & \\
\hline Economic variables & Estimated effects & Employment variables & Estimated effects \\
\hline Turnover & & Total employment & \\
\hline Permanent mean effect & $\begin{array}{l}445431^{* * *} \\
(172771)\end{array}$ & Permanent mean effect & -0.154 \\
& & Number of managers & \\
\hline Equity & -35108 & Permanent mean effect & -0.09 \\
\hline Permanent mean effect & $(90779)$ & & $(0.314)$ \\
\hline Financial autonomy & & Proportion of managers & \\
\hline Permanent mean effect & $\begin{array}{l}2.921^{* *} \\
(1.479)\end{array}$ & Permanent mean effect & -0.003 \\
& 2430 & & $2010)$ \\
\hline Number of observations & $2008-2016$ & & $2008-2015$ \\
\hline Study period & $90 / 180$ & & $84 / 168$ \\
\hline Nb. of treated/controls & & & \\
\hline
\end{tabular}

Notes: The signs $* * *, * *$ and $*$ correspond respectively to the statistically significant coefficients at $1 \%, 5 \%$ and $10 \%$. Standard errors in parentheses are robust to both heteroscedasticity and autocorrelation 
Table 9: Indirect annual effect of the Nanoelec TRI (with another control group)

\begin{tabular}{|c|c|c|c|c|c|}
\hline & $\begin{array}{c}(1) \\
2012\end{array}$ & $\begin{array}{c}(2) \\
2013\end{array}$ & $\begin{array}{c}(3) \\
2014\end{array}$ & $\begin{array}{c}(4) \\
2015\end{array}$ & $\begin{array}{c}(5) \\
2016\end{array}$ \\
\hline \multicolumn{6}{|c|}{ Financial variables } \\
\hline \multicolumn{6}{|l|}{ Turnover } \\
\hline Annual effects & $\begin{array}{l}43,695 \\
(145,666) \\
\end{array}$ & $\begin{array}{l}-1,319 \\
(137,887)\end{array}$ & $\begin{array}{l}100,766 \\
(190,129) \\
\end{array}$ & $\begin{array}{l}448,664 * \\
(238,353)\end{array}$ & $\begin{array}{l}521,770 * \\
(299,121) \\
\end{array}$ \\
\hline \multicolumn{6}{|l|}{ Equity } \\
\hline Annual effects & $\begin{array}{l}14.39 \\
(67,293)\end{array}$ & $\begin{array}{l}-7,375 \\
(84,476)\end{array}$ & $\begin{array}{l}-60,620 \\
(107,157)\end{array}$ & $\begin{array}{l}-20,933 \\
(117,058)\end{array}$ & $\begin{array}{l}-13,235 \\
(145,744)\end{array}$ \\
\hline \multicolumn{6}{|l|}{ Financial autonomy } \\
\hline Annual effects & $\begin{array}{l}-2.118 \\
(1.555) \\
\end{array}$ & $\begin{array}{l}-0.457 \\
(1.508) \\
\end{array}$ & $\begin{array}{l}1.943 \\
(1.811) \\
\end{array}$ & $\begin{array}{l}2.38 \\
(1.94) \\
\end{array}$ & $\begin{array}{l}5.55^{*} \\
(2.043) \\
\end{array}$ \\
\hline $\mathrm{Nb}$. of observations & 2430 & 2430 & 2430 & 2430 & 2430 \\
\hline \multicolumn{6}{|c|}{ Employment variables } \\
\hline Total employment & & & & & \\
\hline Annual effects & $\begin{array}{l}-0.404 \\
(1.049)\end{array}$ & $\begin{array}{l}0.475 \\
(1.003)\end{array}$ & $\begin{array}{l}-0.19 \\
(1.118)\end{array}$ & $\begin{array}{l}-0.232 \\
(1.568)\end{array}$ & - \\
\hline Number of managers & & & & & - \\
\hline Annual effects & $\begin{array}{l}-0.286 \\
(0.354) \\
\end{array}$ & $\begin{array}{l}0.252 \\
(0.343) \\
\end{array}$ & $\begin{array}{l}-0.324 \\
(0.43)\end{array}$ & $\begin{array}{l}0.152 \\
(0.454) \\
\end{array}$ & - \\
\hline Proportion of managers & & & & & - \\
\hline Annual effects & $\begin{array}{l}-0.027 * * \\
(0.011) \\
\end{array}$ & $\begin{array}{l}0.005 \\
(0.012)\end{array}$ & $\begin{array}{l}0.0004 \\
(0.012)\end{array}$ & $\begin{array}{l}0.015 \\
(0.012)\end{array}$ & - \\
\hline Nb. of observations & 2016 & 2016 & 2016 & 2016 & - \\
\hline
\end{tabular}

Notes: The signs $* * *, * *$ and $*$ correspond respectively to the statistically significant coefficients at $1 \%, 5 \%$ and $10 \%$. Standard errors in parentheses are robust to both heteroscedasticity and autocorrelation. 